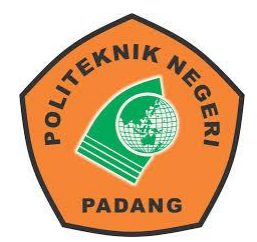

Jurnal IImiah Rekayasa Sipil

Available online at : http://ejournal2.pnp.ac.id/index.php/jirs/

Terakreditasi SINTA Peringkat 5

\title{
Analisis Konten pada Kriteria Green Road pada Dokumen Kontrak Konstruksi Jalan Kota Payakumbuh
}

\author{
${ }^{1}$ Rahmad Aulia Nahar, ${ }^{2}$ Yossyafra, ${ }^{3}$ Bayu Martanto Adji \\ 1,2,3 Jurusan Teknik Sipil, Fakultas Teknik, Universitas Andalas \\ 1'madcimpagolumuik@gmail.com , ${ }^{2}$ yossyafra@ft.unand.ac.id, ${ }^{3}$ bayu@ft.unand.ac.id
}

\begin{abstract}
Road construction has negative side effects on the environment, including reduced non-renewable natural resources, increased emissions, construction waste, reduced productive land and damaged ecosystems. To minimize this problem environmentally friendly efforts are needed in the implementation of road construction. One of the efforts made is to use the concept of greenroad. This concept can be applied at every stage of the implementation of road construction, especially at the stage of road construction and maintenance. This study aims to assess the application of greenroad criteria in construction contract documents using the Content Analysis method. While the case study examined is the Payakumbuh City Road Rehabilitation / Maintenance Contract document in 2016, 2017 and 2018 with a contract value above four billion rupiah. Greenroad assessment criteria use PUPR Minister Circular Number 04 / SE / M / 2018 concerning GreenRoad Ranking Guidelines. In this guide the assessment of greenroads is grouped into five categories, 35 subcategories and 84 criteria. The categories are Conservation of environment, water, air and nature (KL), Provision of transportation and community (TM), Construction implementation activities (AK), Use of materials and natural resources (MS), Pavement technology (TP). The criteria contained in each subcategory have a weighted value. The maximum total value possible in this scoring system is 100. While the greenroad ranking system is divided into four levels, represented by the number of stars. While the greenroad ratings for contracts in 2017 and 2018 are 2 stars with 15.01 each. The increase in value in 2017 is in the AK category with a value of 3.36 in 2016 to 5.46 in 2017. While the opportunity to add green road criteria to the Periodic Road Rehabilitation/ Maintenance contract can be applied in the GCC (general terms of the contract) and technical specifications as many as 26 criteria.
\end{abstract}

Keywords: green road, adjusment criteria, content analisys, contract

\section{Abstrak}

Pembangunan jalan memiliki efek samping negatif terhadap lingkungan, diantaranya berkurangnya sumber daya alam tak terbarukan, peningkatan emisi, peningkatan limbah konstruksi, berkurangnya lahan produktif, dan rusaknya ekosistem. Untuk meminimalisir permasalahan tersebut diperlukan upaya-upaya ramah lingkungan dalam pelaksanaan pembangunan jalan. Salah satunya adalah dengan menggunakan konsep green road. Konsep ini dapat diterapkan pada setiap tahapan pelaksanaan pembangunan jalan, terutama pada tahap konstruksi dan pemeliharaan jalan. Penelitian ini bertujuan untuk menilai penerapan kriteria-kriteria green road pada dokumen

\section{Informasi Artikel}

Diterima Redaksi : 18-02-2020 | Selesai Revisi : 15-04-2020 | Diterbitkan Online : 30-04-2020 
kontrak konstruksi dengan menggunakan metoda Analisis Konten pada. Sedangkan studi kasus yang diteliti adalah dokumen Kontrak Rehabilitasi/ Pemeliharaan Jalan Kota Payakumbuh pada tahun 2016, 2017 dan 2018 dengan nilai kontrak diatas empat miliar rupiah. Kriteria penilaian green road (jalan hijau) menggunakan SE Menteri PUPR No. 04/SE/M/2018 tentang Pedoman Pemeringkatan Jalan Hijau. Dalam pedoman ini penilaian jalan hijau dikelompokkan kedalam lima kategori, 35 subkategori dan 84 kriteria. Adapun kategori tersebut yaitu Konservasi lingkungan, air, udara dan alam (KL), Penyediaan transportasi dan masyarakat (TM), Aktifitas pelaksanaan konstruksi (AK), Penggunaan material dan sumber daya alam (MS), Teknologi perkerasan (TP). Kriteria-kriteria yang terdapat dalam subkategori masing-masing memiliki bobot nilai. Total nilai maksimal yang mungkin didapatkan dalam sistem penilaian ini adalah 100 . Sedangkan sistim peringkat jalan hijau ini dibagi empat tingkatan, yang diwakili dengan jumlah bintang. Dari hasil analisis didapatkan peringkat green road pada kontrak tahun 2016 adalah bintang 2, dengan nilai 12,91. Sedangkan peringkat green road untuk kontrak tahun 2017 dan 2018 adalah bintang 2 dengan niai masing-masing 15,01. Peningkatan nilai pada tahun 2017 terdapat pada kategori AK dengan nilai 3,36 pada tahun 2016 menjadi 5,46 pada tahun 2017. Sedangkan peluang penambahan kriteria green road pada kontrak Rehabilitasi/ Pemeliharaan Berkala Jalan dapat diterapkan dalam SSUK (syarat-syarat umum kontrak) dan spesifikasi teknis sebanyak 26 kriteria.

Kata kunci: green road, kriteria penilaian, Analisis Konten pada, kontrak.

(C) 2020 Jurnal IImiah Rekayasa Sipil

\section{Pendahuluan}

Proses penyelenggaraan jalan yang tidak tepat dapat memberikan dampak negatif terhadap lingkungan. Beberapa efek negatif tersebut yaitu meningkatnya emisi pada proses konstruksi dan pemeliharaan, peningkatan limbah yang dihasilkan pada proses konstruksi, berkurangnya lahan produktif akibat pembukaan jalan baru, rusaknya ekosistim dan berbagai dampak lingkungan yang efeknya bisa dirasakan langsung ataupun dikemudian hari [8]. Secara umum sektor konstruksi menggunakan $50 \%$ sumber daya alam, $40 \%$ energi dan $16 \%$ air [12].

\section{Salah satu konsep jalan ramah lingkungan yang} dikenal yaitu konsep green road. Green road construction atau konstruksi jalan hijau adalah sebuah gerakan berkelanjutan yang mencitacitakan terciptanya konstruksi jalan sejak tahap perencanaan, pelaksanaan, dan pemakaian produk konstruksi yang ramah lingkungan, efisien dalam pemakaian energi dan sumber daya, serta dengan biaya rendah [7].

Penerapan konsep jalan yang ramah lingkungan pada penyelenggaraan jalan haruslah dapat kita lihat pada dokumendokumen pemerintahan terkait. Dokumen yang dimaksud merupakan pedoman aplikatif yang digunakan pada setiap siklus penyelenggaraan jalan. Selain berisikan NSPM terkait dokumendokumen penyelenggaraan jalan harus mengatur tentang aturan dan kebijakan dampak lingkungan dengan tegas dan aplikatif. Oleh karena itu diperlukan suatu sistim penilaian yang jelas dan terukur sebagai pedoman Analisis Konten pada green road pada setiap dokumen penyelenggaraan jalan.

Pada penelitian sebelumnya [6] mengelompokkan tujuh aspek dan enam belas faktor green construction, yaitu: perencanaan dan penjadwalan proyek konstruksi, sumber

\section{Informasi Artikel}

Diterima Redaksi : 18-02-2020 | Selesai Revisi : 15-04-2020 | Diterbitkan Online : 30-04-2020 
dan siklus material, rencana perlindungan lokasi pekerjaan, manajemen limbah konstruksi, program kesehatan dan keselamatan kerja, pemilihan dan operasional peralatan konstruksi, dokumentasi, pelatihan bagi subkontraktor, pengurangan jejak ekologis tahap konstruksi, kualitas udara tahap konstruksi, efisiensi air, tepat guna lahan, efisiensi energi dan manajemen lingkungan proyek konstruksi. Enam belas faktor tersebut lalu dikelompokkan menjadi tujuh aspek green construction yaitu : konservasi energi, konservasi air, tepat guna lahan, sumber dan siklus material, manajemen lingkungan bangunan, kualitas udara, kesehatan dan kenyamanan dalam proyek

Analisis dan pengukuran dalam penelitian ini dilakukan terhadap dokumen kontrak Rehabilitasi/ Pemeliharaan Berkala Jalan Kota Payakumbuh dengan nilai diatas 4 milyar rupiah. Kriteria penilaian green road menggunakan SE Menteri PUPR, Nomor 04/SE/M/2018 tentang Pedoman Pemeringkatan Jalan Hijau. Sedangkan metoda penelitian menggunakan metode Analisis Konten pada kualitatif yang memungkinkan peneliti melakukan kategorisasi terhadap objek penelitian.

Penelitian ini bertujuan untuk menilai Analisis Konten pada green road pada dokumen kontrak konstruksi jalan Kota Payakumbuh. Sehingga hasil dari penelitian ini dapat memberikan gambaran penerapan konsep green road dalam kontrak konstruksi penyelenggaraan jalan Kota Payakumbuh.

\section{Metode Penelitian}

Content analysis (Analisis Isi)

Secara umum pengertian dari content analysis (analisis isi) adalah suatu metoda yang digunakan untuk mengetahui kecenderungan isi komunikasi dalam suatu teks dokumen.

Secara umum langkah-langkah yang dilakukan dalam metoda analisis isi yaitu :

1. Merumuskan masalah penelitian

2. Melakukan studi pustaka

3. Melakukan sampling terhadap sumbersumber data yang telah dipilih

4. Membuat kategorisasi dan pedoman pengkodean

5. Mengumpulkan data suatu sampel dokumen dan pengkodean

6. Membuat skala dan item berdasarkan kriteria tertentu

7. Menyajikan data dan memberikan interpretasi atau penafsiran

Berdasarkan pendekatan yang digunakan, analisis isi dibagi menjadi dua, yaitu analisis isi kuantitatif dan analisis isi kualitatif. Dalam perspektif metodologi kuantitatif, analisis isi merupakan salah satu pengukuran variabel, sedangkan dalam metodologi kualitatif berhubungan dengan analisis data dan tafsir teks.

Penelitian ini dilakukan terhadap penyelenggara jalan Kota Payakumbuh, dalam hal ini adalah Dinas Pekerjaan Umum dan Penataan Ruang Kota Payakumbuh. Objek yang diteliti adalah Analisis Konten pada konsep green road yang ada dalam dokumen penyelenggaraan jalan Kota Payakumbuh.

Dari observasi awal ditemui bahwa penerapan konsep green road belum menjadi perhatian

\section{Informasi Artikel}

Diterima Redaksi : 18-02-2020 | Selesai Revisi : 15-04-2020 | Diterbitkan Online : 30-04-2020 
khusus dalam pelaksanaan rutinitas pekerjaan penyelenggaraan jalan. $\mathrm{Hal}$ ini harus ditingkatkan untuk memenuhi terlaksananya Peraturan Menteri Pekerjaan Umum dan Perumahan Rakyat (PUPR) no. 5 tahun 2015 tentang Pedoman Umum Implementasi Konstruksi Berkelanjutan pada Penyelenggaraan Infrastruktur Bidang Pekerjaan Umum dan Permukiman. Dalam peraturan ini menekankan bahwa penyelenggara jalan harus mengAnalisis Konten padakan pendekatan konstruksi berkelanjutan dengan memenuhi persyaratan keandalan teknis dan prinsip berkelanjutan.

Dalam penelitian ini populasi data yang digunakan adalah kontrak konstruksi penyelenggaraan jalan Kota Payakumbuh.

Sedangkan sampel yang digunakan adalah kontrak konstruksi pekerjaan Rehabilitasi/ Pemeliharaan Berkala Jalan dengan nilai diatas empat miliar rupiah. Pemilihan kontrak dengan nilai diatas empat miliar rupiah ditujukan untuk mempersempit objek penelitian dengan pembahasan bagian-bagian kontrak yang lebih kompleks, baik secara teknis maupun secara administrasi. Rentang waktu dari kontrak konstruksi yang dijadikan objek penelitian adalah tiga tahun, yaitu tahun 2016, 2017 dan 2018. Rentang tahun ini dipilih karena adanya kewajiban penyelenggara jalan untuk memenuhi penerapan Permen. PU dan Perumahan Rakyat RI nomor 05/PRT/M/2015 yang efektif berlaku sejak tahun 2016 .

\section{Analisis Kriteria Greenroad Dengan Menggunakan Pedoman Pemeringkatan Jalan Hijau \\ Pada tahun 2018 Kementerian Pekerjaan} Umum dan Perumahan Rakyat Mengeluarkan Pedoman Pemeringkatan Jalan Hijau. Pedoman pemeringkatan jalan hijau ini dilakukan pada tahap perencanaan dan pelaksanaan konstruksi. Karena penelitian ini dilakukan pada tahapan pelaksanaan konstruksi, maka penulis akan mengidentifikasi kriteria-kriteria yang bisa digunakan pada tahap pelaksanaan konstruksi untuk dijadikan dasar penilaian penerapan green road dalam kontrak konstruksi.

Dalam pedoman ini kriteria jalan hijau dikelompokkan kedalam lima kategori, yaitu (1) Konservasi lingkungan, air, udara dan alam, (2) Penyediaan transportasi dan masyarakat, (3) Aktifitas pelaksanaan konstruksi, Penggunaan material dan sumber daya alam, (5) Teknologi perkerasan. Lima kategori tersebut terbagi dalam total 35 subkategori dan 84 kriteria. Masing-masing kriteria memiliki bobot nilai untuk mengukur tingkat penerapan green road. Lima kategori tersebut adalah sebagai berikut :

Kategori konservasi lingkungan, air, udara, dan alam (KL)

Dalam kategori $\mathrm{KL}$ ini terdapat 9 subkategori dengan total 29 kriteria. Adapun subkategori dan kriteria dalam kategori $\mathrm{KL}$ ini dapat dilihat pada tabel 1 dibawah ini :

\section{Informasi Artikel}

Diterima Redaksi : 18-02-2020 | Selesai Revisi : 15-04-2020 | Diterbitkan Online : 30-04-2020 
Tabel 1. Subkategori, Kriteria dan Bobot

Penilaian Kategori TM

\begin{tabular}{|c|c|c|}
\hline Subkategori & Kriteria & Nila \\
\hline $\begin{array}{l}\text { TM-1 Penataan } \\
\text { ornamen dan } \\
\text { lansekap jalan }\end{array}$ & $\begin{array}{l}\text { Menata dan menyediakan } \\
\text { landskap yang dilengkapi } \\
\text { dengan ornamen yang artistik } \\
\text { dan berbasis muatan lokal }\end{array}$ & 0,97 \\
\hline $\begin{array}{l}\text { TM-2 Penyediaan } \\
\text { fasilitas henti } \\
\text { menikmati } \\
\text { pemandangan } \\
\text { menarik }\end{array}$ & $\begin{array}{l}\text { Menyediakan akses ke } \\
\text { fasilitas henti (tempat parkir) } \\
\text { atau agar pengguna jalan } \\
\text { dapat melihat pemandangan } \\
\text { menarik }\end{array}$ & 0,77 \\
\hline $\begin{array}{l}\text { TM-3 Penyediaan } \\
\text { akses dan } \\
\text { fasilitas } \\
\text { pengguna }\end{array}$ & $\begin{array}{l}\text { 1. Meningkatkan mualitas dan/ } \\
\text { kuantitas fasilitas peneduh } \\
\text { dengan tanaman atau } \\
\text { bangunan peneduh pada area } \\
\text { parkir }\end{array}$ & 0,77 \\
\hline angkutan umum & $\begin{array}{l}\text { 2. Menyediakan akses jalan } \\
\text { untuk kendaraan dan pejalan } \\
\text { kaki ke moda angkutan lainnya }\end{array}$ & 0,77 \\
\hline & $\begin{array}{l}\text { 3. Menyediakan peerhentian } \\
\text { angkutan umum/ bus yang } \\
\text { dilengkapi dengan akses } \\
\text { pejalan kaki dari/ ke jalur } \\
\text { pejalan kaki } \\
\text { 4. Menyediakan fasilitas parkir } \\
\text { sepeda, baik pada area parkir } \\
\text { atau terminal }\end{array}$ & 0,77 \\
\hline \multirow{5}{*}{$\begin{array}{l}\text { TM-4 } \\
\text { Perancangan } \\
\text { geometrik dan } \\
\text { fasilitas } \\
\text { perlengkapan } \\
\text { jalan untuk } \\
\text { menekan } \\
\text { penggunaan } \\
\text { energi }\end{array}$} & $\begin{array}{l}\text { 1. Melakukan inovasi terhadap } \\
\text { transportasi masyarakat }\end{array}$ & 0,66 \\
\hline & $\begin{array}{l}\text { 2. Merancang geometrik jalan } \\
\text { yang mendukung kawasan } \\
\text { konservasi/ habitat yang } \\
\text { dilewati } \\
\text { 3. Penggunaan fasilitas } \\
\text { perlengkapan jalan untuk } \\
\text { pengaturan lalu lintas pada } \\
\text { saat pelaksanaan konstruksi }\end{array}$ & 0,44 \\
\hline & $\begin{array}{l}\text { 4. Penggunaan fasilitas } \\
\text { perlengkapan jalan untuk } \\
\text { pengaturan lalu lintas pada } \\
\text { saat operasional }\end{array}$ & 0,44 \\
\hline & $\begin{array}{l}\text { 5. Merancang geometrik jalan } \\
\text { guna menjamin keselamatan } \\
\text { dan kenyamanan pengguna } \\
\text { jalan }\end{array}$ & 0,22 \\
\hline & $\begin{array}{lr}\text { 6. Merancang fasilitas } \\
\text { perlengkapan jalan yang } \\
\text { mudah dipelihara. }\end{array}$ & 0,22 \\
\hline \multirow{3}{*}{$\begin{array}{l}\text { TM-5 } \\
\text { Pelaksanaan } \\
\text { audit } \\
\text { keselamatan } \\
\text { jalan oleh } \\
\text { pihak } \\
\text { independen }\end{array}$} & $\begin{array}{l}\text { 1. Melaksanakan audit } \\
\text { keselamatan pada tahap pra } \\
\text { konstruksi }\end{array}$ & 0,57 \\
\hline & $\begin{array}{l}\text { 2. Melakukan audit pada tahap } \\
\text { pelaksanaan konstruksi }\end{array}$ & 0,57 \\
\hline & $\begin{array}{l}\text { 3. Melakukan audit pasca } \\
\text { konstruksi }\end{array}$ & 0,57 \\
\hline \multirow[t]{2}{*}{$\begin{array}{l}\text { TM-6 Penyediaan } \\
\text { akses dan } \\
\text { fasilitas } \\
\text { pejalan kaki }\end{array}$} & $\begin{array}{l}\text { 1. Melengkapi jalur pejalan kaki } \\
\text { dengan peneduh } \\
\text { 2. Melakukan perancangan jalur } \\
\text { pejalan kaki baru dengan } \\
\text { memperlihatkan aspek } \\
\text { kemudahan dalam masa } \\
\text { pemeliharaan }\end{array}$ & 0,50 \\
\hline & $\begin{array}{l}\text { 3. Menyediakan jembatan } \\
\text { penyeberangan atau zebra }\end{array}$ & 0 \\
\hline
\end{tabular}

cross yang terhubung dengan jalur pejalan kaki

4. Memperbaiki / merehabilitasi 0,50 jalur pejalan kaki yang terhubung engan akses jalan minor, pelandaian, jalur pemandu, dengan mempertimbangkan aspek kemudahan pemeliharaan

5. Menyediakan street furniture yang mempertimbangkan kemudahan dalam pemeliharaan

6. Melakukan perhitungan jumlah pejalan kaki disepanjang koridor sebelum perancangan 0,25 jalur pejalan

1. Menyampaikan rencana 0,31 TM-7 Pelibatan proyek jalan kepada peran serta masyarakat

$\begin{array}{lll}\text { masyarakat } & \text { 2. Melibatkan masyarakat dalam } 0,31\end{array}$

dalam penentuan kebutuhan faslitas komunitas lokal

perencanaan

3. Melibatkan masyarakat agar 0,31 perencanaan dan pelaksanaan pekerjaan mempertimbangkan kearifan lokal

1. Merancang baru jalur sepeda 0,25

TM-8 Penyediaan 2. Melebarkan jalur sepeda 0,25

akses dan 3. Merancang ruang untuk jalur 0,25 fasilitas berbagi

pesepeda 4. Memperkeras bahu jalan 0,25 untuk jalur sepeda

5. Menyediakan fasilitas 0,25 pelengkap sepeda

6. Melakukan perhitungan 0,12 jumlah pesepeda disepanjang koridor sebelum perancangan jalur sepeda

7. Memperbaiki jalur sepeda

8. Menyediakan jembatan penyeberangan tanjakan yang 0,12 baru

9. Melengkapi rambu-rambu jalur 0,12 sepeda

Sumber : Kementerian Pekerjaan Umum dan Perumahan

Rakyat, 2018

Kategori aktifitas pelaksanaan konstruksi (AK)

Dalam kategori ini terdapat 10 subkategori dan

11 kriteria yang dapat dilihat dalam tabel 2 berikut :

\section{Informasi Artikel}

Diterima Redaksi : 18-02-2020 | Selesai Revisi : 15-04-2020 | Diterbitkan Online : 30-04-2020 
Tabel 2. Subkategori, Kriteria dan Bobot Penilaian Kategori AK

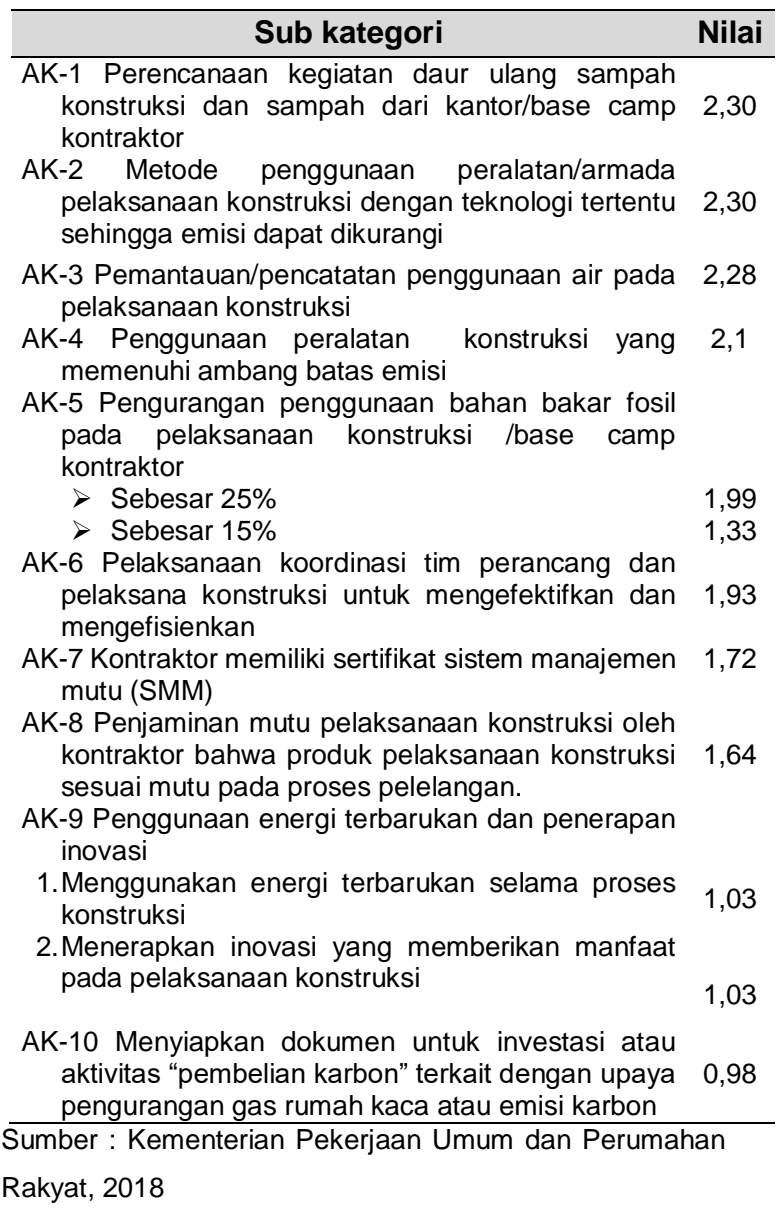

Kategori material dan sumber daya alam (MS)

Terdapat 6 subkategori dalam kategori MS ini, dengan 6 kriteria penilaian yang dapat dilihat pada tabel 3 berikut :

Tabel 3. Subkategori, Kriteria dan Bobot Penilaian Kategori MS

\begin{tabular}{cclcc}
\hline \multicolumn{2}{c}{ Sub kategori } & \multicolumn{2}{c}{ Kriteria } & Nilai \\
\hline MS-1 & 1. & Menggunakan minimal $50 \%$ & 5,64 \\
Penggunaan & material daur ulang yang & \\
material daur & disyaratkan untuk pilihan 1 dan \\
ulang pada & pilihan 2, atau menggunakan \\
proyek jalan, & minimal 60\% material daur \\
baik & yang & $\begin{array}{l}\text { ulang yang disyaratkan untuk } \\
\text { sedang }\end{array}$ & pilihan 3 dan pilihan 4 \\
dibangun atau & 2. $\begin{array}{l}\text { Menggunakan minimal 40\% } \\
\text { material daur ulang yang }\end{array}$
\end{tabular}

$\begin{array}{ll}\text { pada jalan } & \begin{array}{l}\text { disyaratkan untuk pilihan 1 dan } \\ \text { yang berbeda } \\ \text { pilihan 2, atau menggunakan } \\ \text { minimal 50\% material daur }\end{array} \\ & \text { ulang yang disyaratkan untuk } \\ & \text { pilihan 3 dan pilihan } 4 \\ \text { 3. } & \text { Menggunakan minimal 30\% } \\ & \text { material daur ulang yang } \\ & \text { disyaratkan untuk pilihan 1 dan } \\ \text { pilihan 2, atau menggunakan } & \text { minimal 40\% material daur } \\ & \text { ulang yang disyaratkan untuk } \\ \text { pilihan 3 dan pilihan 4 }\end{array}$

4. Menggunakan minimal $20 \%$ material daur ulang yang disyaratkan untuk pilihan 1 dan pilihan 2, atau menggunakan minimal $30 \%$ material daur ulang yang disyaratkan untuk pilihan 3 dan pilihan 4

5. Menggunakan minimal $10 \%$ material daur ulang yang disyaratkan untuk pilihan 1 dan pilihan 2, atau menggunakan minimal 20\% material daur ulang yang disyaratkan untuk 1,88 pilihan 3 dan pilihan 4

MS-2 Penggunaan ulang material bongkaran (selain tanah) di lokasi setempat

MS-3

Penggunaan material lokal seperti

agregat, aspal, semen, tulangan, pohon yang dihitung jumlah dari total biaya dalam radius maksimum 80 $\mathrm{km}$ dari pusat lokasi proyek atau jumlah dari total berat dari jarak maksimum 160 $\mathrm{km}$ dari pusat lokasi proyek.

1. Sekurang-kurangnya $90 \%$

2. Sekurang-kurangnya $80 \%$

1. $95 \%$ dari total biaya material, perakitan dan pengiriman 3,60 didalam radius maks. $80 \mathrm{~km}$ dari pusat lokasi proyek, atau minimal $95 \%$ dari total berat masing-masing material diangkut dari lokasi yang jaraknya maks. $160 \mathrm{~km}$ pusat lokasi proyek

2. $90 \%$ dari total biaya material, perakitan dan pengiriman didalam radius maks. $80 \mathrm{~km}$ dari pusat lokasi proyek, atau minimal $95 \%$ dari total berat masing-masing material diangkut dari lokasi yang jaraknya maks. $240 \mathrm{~km}$ pusat lokasi proyek

3. $84 \%$ dari total biaya material perakitan dan pengiriman didalam radius maks. $80 \mathrm{~km}$ dari pusat lokasi proyek, atau minimal $95 \%$ dari total berat masing-masing material diangkut dari lokasi yang jaraknya maks. $360 \mathrm{~km}$ pusat lokasi proyek

4. $75 \%$ dari total biaya material, perakitan dan pengiriman didalam radius maks. $80 \mathrm{~km}$ dari pusat lokasi proyek, atau minimal $95 \%$ dari total berat masing-masing material diangkut dari lokasi yang

Informasi Artikel

Diterima Redaksi : 18-02-2020 | Selesai Revisi : 15-04-2020 | Diterbitkan Online : 30-04-2020 
jaraknya maks. $540 \mathrm{~km}$ pusat lokasi proyek

5. $60 \%$ dari total biaya material, perakitan dan pengiriman didalam radius maks. $80 \mathrm{~km}$ dari pusat lokasi proyek, atau minimal $95 \%$ dari total berat masing-masing material diangkut dari lokasi yang jaraknya maks. $800 \mathrm{~km}$ pusat lokasi proyek

MS-4 Penggunaan minimal 90\% material tanah galian untuk timbunan setempat

MS-5 Pemanfaatan material bongkaran di luar lokasi proyek

MS-6 Lampu 1. 100\% $\begin{array}{lll}\text { penerangan } & \text { 2. } 80 \% & 1,35\end{array}$ jalan yang $3.60 \% \quad 1,01$ menggunakan 4. $40 \% \quad 0,68$ sumber daya $5.20 \% \quad 0,34$ energy terbarukan

Sumber : Kementerian Pekerjaan Umum dan Perumahan Rakyat, 2018

Kategori teknologi perkerasan (TP)

Kategori TP (teknologi perkerasan) memiliki subkategori berjumlah 2 dengan total 5 kriteria penilan pada masing-masing subkategori. Pada kategori TP ini terdapat pilihan antara subkategori TPK (teknologi perkerasan untuk kendaraan) dengan subkategori TPP (perkerasan untuk pejalan kaki). Dalam penilaian sebuah proyek dipilih subkategori dengan perolehan nilai tertinggi antara TPK dan TPP. Subkategori dan kriteria dalam kategori TP ini dapat dilihat pada tabel 4 dibawah ini :

Tabel 4. Subkategori, Kriteria dan Bobot Penilaian Kategori TP

\begin{tabular}{|c|c|}
\hline Subkategori & Nilai \\
\hline $\begin{array}{l}\text { TPK-1 Merancang umur rencana perkerasan lentur } \\
40 \text { tahun untuk lapisan pondasi dan } 20 \text { tahun } \\
\text { untuk lapisan permukaan. Umur rencana } \\
\text { perkerasan beton adalah } 40 \text { tahun }\end{array}$ & 5,88 \\
\hline $\begin{array}{l}\text { TPK-2 Penggunaan campuran dingin untuk } \\
\text { pekerasan lentur }\end{array}$ & 4,04 \\
\hline $\begin{array}{l}\text { TPK-3 Penggunaan perkerasan porus yang } \\
\text { berfungsi untuk meresapkan dan mengaliran air } \\
\text { permukaan di perkerasan jalan yang dilengkapi } \\
\text { dengan fasilitas outlet air jika sudah melebihi } \\
\text { kapasitas. }\end{array}$ & 3,94 \\
\hline
\end{tabular}

TPK-4 Merancang permukaan perkerasan yang 3,29 dapat mengurangi kebisingan

TPK-5 Merancang campuran beraspal hangat Pelaksanaan pencampuran dilakukan pada 3,05 temperature $30^{\circ} \mathrm{C}$. Temperatur pencampuran yang dimaksud adalah pada saat campuran keluar dari drum pencampuran (untuk drum) atau pugmill (untuk batch)

TPP-1 Perancangan perkerasan pejalan kaki yang 5,88 mempertahankan fungsi trotoar.

TPP-2 Penggunaan material yang dibuat tanpa 4,04 pemanasan.

TPP-3 Perancangan permukaan perkerasan porus untuk meningkatkan pengendalian aliran dan 3,94 kualitas limpasan air permukaan.

TPP-4 Perancangan permukaan perkerasan yang kekesatanna memenuhi persyaratan untuk 3,29 pejalan kaki.

TPP-5 Penggunaan material yang dibuat dengan pemanasan lebih rendah dari temperatur 0,98 standar.

Sumber : Kementerian Pekerjaan Umum dan Perumahan

Rakyat, 2018

Dalam sistim penilaian ini ditemukan 5 kriteria yang berada pada tahapan perencanaan, yaitu pada Subkatogori TM-5 (kriteria 1), Subkategori TM-6, (kriteria 6), Subkategori TM-7 (kriteria 1), Subkategori TM-7 (kriteria 2) dan Subkategori TM-7 (kriteria 3). Diketahui total nilai tertinggi yang bisa didapatkan pada sistem penilaian ini adalah 100 poin

Sistim peringkat jalan hijau ini dibagi empat tingkatan. Tiap tingkatan diwakili oleh jumlah bintang, tergantung dari jumlah nilai yang didapatkan. Nilai teersebut didapatkan dengan menjumlahkan nilai pada kriteria didalam subkategori dan kategori jalan hijau. Untuk lebih jelasnya dapat dilihat pada tabel 5 dibawah ini :

Tabel 5. Peringkat Jalan Hijau

\begin{tabular}{|c|c|}
\hline Peringkat & Nilai Peringkat Jalan Hijau \\
\hline 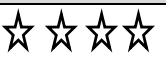 & $\begin{array}{l}\text { Nilai penerapan kriteria jalan hijau } \geq \\
45,00\end{array}$ \\
\hline 头 & $\begin{array}{l}\text { Nilai penerapan kriteria jalan hijau } \\
\text { antara } 20,01 \text { dan } 44,99\end{array}$ \\
\hline 文公 & $\begin{array}{l}\text { Nilai penerapan kriteria jalan hijau } \leq \\
20,00\end{array}$ \\
\hline
\end{tabular}

\section{Informasi Artikel}

Diterima Redaksi : 18-02-2020 | Selesai Revisi : 15-04-2020 | Diterbitkan Online : 30-04-2020 


Jalan yang telah memenuhi
$\begin{aligned} & \text { persyaratan teknis jalan, memiliki } \\ & \text { analisis life cycle cost, dan dokumen } \\ & \text { lingkungan }\end{aligned}$
Sumber : Kementerian Pekerjaan Umum dan Perumahan
Rakyat, 2018

Analisis Konten pada Green road dalam Dokumen Penyelenggaraan Jalan

Analisis dilakukan terhadap isi setiap bagian dalam kontrak. Masing-masing komponen yang ada dalam Dokumen Kontrak Konstruksi Jalan Kota Payakumbuh akan diidentifikasi dan dipilah bagian-bagian yang berhubungan dengan materi green roads. Setiap pembahasan yang berkaitan dengan green road akan ditandai dan diberikan kode sesuai dengan kelompok klasifikasi kriteria green roads yang ada adalam Pedoman Pemeringkatan Jalan Hijau.

Analisis juga dilakukan terhadap kriteria-kriteria pedoman jalan hijau yang dapat diterapkan dalam kontrak untuk meningkatkan penerapan jalan yang ramah lingkungan. Kriteria-kriteria jalan hijau yang tersedia didalam kontrak akan diberikan nilai sesuai sistem penilaian jalan hijau pada Pedoman Pemeringkatan Jalan Hijau Kementerian Pekerjaan Umum dan Perumahan Rakyat tahun 2018

Penilaian dilakukan terhadap sampel kontrak konstruksi pada masing-masing tahun anggaran. Setelah itu akan dibandingkan penerapan kriteria-kriteria pemeringkatan jalan hijau antara tiap tahun kontrak konstruksi yang dinilai. Dari hasil penilaian tersebut akan dapat disimpulkan tingkat penerapan kriteria-kriteria pemeringkatan jalan hijau didalam kontrak konstruksi penyelenggaraan jalan Kota Payakumbuh yang disimbolkan dengan jumlah bintang sesuai dengan perolehan nilai total.

\section{Hasil dan Pembahasan}

Identifikasi kriteria-kriteria green road dilakukan terhadap kontrak konstrusi Rehabilitasi/ Pemeliharaan Berkala Jalan Kota Payakumbuh Tahun Anggaran 2016, 2017, dan 2018. Dalam kontrak tersebut memuat beberapa bagian kontrak, yaitu Syarat-syarat Umum Kontrak (SSUK), Syarat-syarat Khusus Kontrak (SSKK), Spesifikasi Teknis, Dokumen Penawaran, Gambar Rencana, dan Rencana Anggaran Biaya. Bagian-bagian kontrak tersebut berisikan pedoman dan kesepakatan yang harus dilakukan dalam pelaksanaan kontrak konstruksi. Dalam hal ini juga harus memuat ketentuan-ketentuan penerapan green road. Dengan menggunakan Pedoman Penilaian Jalan Hijau penerapan kriteria-kriteria green road dapat diketahui nilai pada masing-masing tahunnya.

Identifikasi Kriteria-kriteria Green road Dalam Kontrak Konstruksi Tahun 2016, 2017 Dan 2018

Kriteria-kriteria green road dapat ditemukan pada subbagian konrak konstruksi, yaitu dalam SSUK, Spesifikasi Teknis dan Dokumen Penawaran. Adapun lingkup pekerjaan dari kontrak konstruksi kegiatan rehabilitasi/ pemeliharaan berkala jalan Kota Payakumbuh tahun anggaran 2016 terdiri dari :

Divisi 1, umum, item pekerjaan yang dilaksanakan adalah pekerjaan plank

\section{Informasi Artikel}

Diterima Redaksi : 18-02-2020 | Selesai Revisi : 15-04-2020 | Diterbitkan Online : 30-04-2020 
proyek, mobilisasi dan manajemen keselamatan lalu lintas.

Divisi 2, drainase, dengan dua item pekerjaan yang dilaksanakan, yaitu pekerjaan selokan dan saluran air dan pekerjaan gorong-gorong dan drainase beton

Divisi 3, pekerjaan tanah, dengan item pekerjaan yang dilaksanakan adalah pekerjaan galian dan pekerjaan penyiapan badan jalan

Divisi 4, pelebaran perkerasan dan bahu jalan, dengan item pekerjaan yang dilaksanakan adalah pelebaran perkerasan dan pekerjaan bahu jalan

Divisi 5, perkerasan berbutir dan perkerasan beton semen, dengan item pekerjaan yang dilaksanakan adalah pekerjaan lapis pondasi agregat dan perkerasan beton semen

Divisi 6, perkerasan aspal, dengan item pekerjaan yang dilaksanakan adalah pekerjaan lapis resap pengikat dan lapis perekat, pekerjaan campuran beraspal panas dan pekerjaan pemeliharaan dengan laburan aspal

Divisi 7, struktur, dengan item pekerjaan yang dilaksanakan adalah pekerjaan beton dan pekerjaan baja tulangan, pekerjaan baja struktur, pekeraan adukan semen dan pekerjaan pasangan batu

Divisi 8, pengembalian kondisi dan pekerjaan minor, dengan item pekerjaan yang dilaksanakan adalah pekerjaan perlengkapan jalan dan pengatur lalu lintas.

Pada subbagian spesifikasi teknis dan subbagian dokumen penawaran dapat kita temukan lingkup pekerjaan konstruksi yang dilaksanakan. Adapun lingkup pekerjaan dari kontrak konstruksi kegiatan Rehabilitasi/ Pemeliharaan Berkala Jalan Kota Payakumbuh Tahun Anggaran 2017 dan 2018 (identik sama), terdiri dari :

Divisi 1, umum, item pekerjaan yang dilaksanakan adalah pekerjaan plank proyek, mobilisasi dan manajemen keselamatan lalu lintas.

Divisi 3, pekerjaan tanah, dengan item pekerjaan yang dilaksanakan adalah pekerjaan galian dan pekerjaan penyiapan badan jalan

Divisi 5, perkerasan berbutir dan perkerasan beton semen, dengan item pekerjaan yang dilaksanakan adalah pekerjaan lapis pondasi agregat

Divisi 6, perkerasan aspal, dengan item pekerjaan yang dilaksanakan adalah pekerjaan lapis resap pengikat dan lapis perekat dan pekerjaan campuran beraspal panas

Divisi 7 , struktur, dengan item pekerjaan yang dilaksanakan adalah pekerjaan beton dan pekerjaan baja tulangan dan pekerjaan pasangan batu

Divisi 8, pengembalian kondisi dan pekerjaan minor, dengan item pekerjaan yang dilaksanakan adalah pekerjaan pengembalian kondisi perkerasan lama dan pekerjaan perlengkapan jalan dan pengatur lalu lintas.

Analisis Penerapan Kriteria-kriteria Green road Dalam Kontrak Konstruksi Tahun 2016 Identifikasi penerapan kriteria-kriteria green road dilakukan pada subbagian kontrak yang

\section{Informasi Artikel}

Diterima Redaksi : 18-02-2020 | Selesai Revisi : 15-04-2020 | Diterbitkan Online : 30-04-2020 
berisikan SSUK, spesifikasi teknis dan dokumen penawaran. Identifikasi ini dilakukan berdasarkan kategori-kategori pedoman jalan hijau.

Tabel 6. Rangkuman Analisis Konten pada green road terhadap kontrak konstrusi rehabilitasi/ pemeliharaan berkala jalan Kota Payakumbuh tahun anggaran 2016

\begin{tabular}{cccc}
\hline Kategori & Subkategori & Kriteria & Nilai \\
\hline \multirow{3}{*}{ KL } & KL-2 & 1 & 2,1 \\
& KL-3 & 2 & 0,66 \\
& KL-7 & 1 & 0,94 \\
& KL-9 & 3 & 0,56 \\
& & 4 & 0,28 \\
& TM-4 & 1 & 0,66 \\
TM & & 3 & 0,44 \\
& & 3 & 0,25 \\
& TM-8 & 5 & 0,25 \\
AK & AK-7 & 1 & 0,12 \\
& AK-8 & 1 & 1,72 \\
TPP & TPP-4 & 1 & 3,29 \\
& Total Nilai & & 12,91 \\
\hline
\end{tabular}

Analisis Penerapan Kriteria-kriteria Green road Dalam Kontrak Konstruksi Tahun 2017 Dan Tahun 2018

Analisis Konten pada penerapan kriteria-kriteria green road dalam kontrak konstruksi pada tahun 2017 dan tahun 2018 memiliki kesamaan kandungan, baik dari segi jumlah, maupun jenis kriteria. Penerapan kriteria-kriteria tersebut dapat dilihat pada tabel 7 berikut :
Tabel 7. Rangkuman Analisis Konten pada green road terhadap kontrak konstruksi rehabilitasi/ pemeliharaan berkala jalan Kota Payakumbuh tahun anggaran 2017 dan tahun 2018

\begin{tabular}{cccc}
\hline Kategori & Subkategori & Kriteria & Nilai \\
\hline \multirow{4}{*}{ KL } & KL-2 & 1 & 2,1 \\
& KL-3 & 2 & 0,66 \\
& KL-7 & 1 & 0,94 \\
& KL-9 & 3 & 0,56 \\
& & 4 & 0,28 \\
& TM-4 & 1 & 0,66 \\
TM & & 3 & 0,44 \\
& & 3 & 0,25 \\
& TM-8 & 5 & 0,25 \\
AK & & 9 & 0,12 \\
& AK-4 & 1 & 2,1 \\
& AK-7 & 1 & 1,72 \\
TPP & AK-8 & 1 & 1,64 \\
& TPP-4 & 1 & 3,29 \\
& Total Nilai & & 15,01 \\
& & &
\end{tabular}

Berdasarkan analisis pada Kontrak Konstruksi Rehabilitasi/ Pemeliharaan Berkala Jalan Kota Payakumbuh Tahun Anggaran 2016, 2017 dan 2018 diatas didapat perbandingan perolehan nilai green road seperti terlihat pada tabel 8 berikut :

Tabel 8. Rekapitulasi Penilaian Green road

\begin{tabular}{lcccc}
\hline & & Nilai & \multicolumn{4}{c}{ Hasil Penilaian } \\
\multicolumn{1}{c}{ Kategori } & Max & $\mathbf{2 0 1 6}$ & $\mathbf{2 0 1 7}$ & $\mathbf{2 0 1 8}$ \\
$\begin{array}{l}\text { KL (Konservasi } \\
\text { Lingkungan air, }\end{array}$ & 26,68 & 4,54 & 4,54 & 4,54 \\
$\begin{array}{l}\text { udara dan alam) } \\
\begin{array}{l}\text { TM (Transportasi } \\
\text { dan Masyarakat) }\end{array}\end{array}$ & 13,72 & 1,72 & 1,72 & 1,72 \\
\end{tabular}

\section{Informasi Artikel}

Diterima Redaksi : 18-02-2020 | Selesai Revisi : 15-04-2020 | Diterbitkan Online : 30-04-2020 


\begin{tabular}{|c|c|c|c|c|}
\hline $\begin{array}{l}\text { AK (Aktifitas } \\
\text { pelaksanaan } \\
\text { Konstruksi }\end{array}$ & 19,31 & 3,36 & 5,46 & 5,46 \\
\hline $\begin{array}{l}\text { MS (Material dan } \\
\text { Sumber daya } \\
\text { alam) }\end{array}$ & 20,09 & 0 & 0 & 0 \\
\hline $\begin{array}{l}\text { TP (Teknologi } \\
\text { Perkerasan) }\end{array}$ & 20,2 & 3,29 & 3,29 & 3,29 \\
\hline Total & 100 & 12,91 & 15,01 & 15,01 \\
\hline
\end{tabular}

Dari perolehan niai diatas, peringkat bintang dapat dilihat pada tabel 9 berikut :

Tabel 9. Peringkat jalan hijau kontrak rehabilitasi/ pemeliharaan berkala jalan Kota

Payakumbuh tahun 2016, 2017 dan 2018

\begin{tabular}{|c|c|c|c|}
\hline Tahun & Nilai & $\begin{array}{c}\text { Rentang } \\
\text { Nilai }\end{array}$ & Peringkat \\
\hline 2016 & 12,91 & $\leq 20,00$ & 头头 \\
\hline 2017 & 15,01 & $\leq 20,00$ & 文文 \\
\hline 2018 & 15,01 & $\leq 20,00$ & 支支 \\
\hline
\end{tabular}

\section{Kesimpulan}

Berdasarkan sistem peringkat jalan hijau, penerapan kriteria-kriteria peringkat jalan hijau pada kontrak Rehabilitasi/ Pemeliharaan Berkala Jalan Kota Payakumbuh tahun 2016, 2017 dan 2018 memiliki peringkat bintang dua. Peringkat bintang dua ini berarti total nilai yang didapatkan kurang atau sama dengan 20, sedangkan peringkat nilai tertinggi yang bisa didapatkan adalah lebih/ sama dengan 45.

Banyaknya kesamaan dari penerapan kriteriakriteria jalan hijau yang ditemui pada ketiga kontrak diatas karena sebagian besar penemuan kriteria-kriteria jalan hijau tersebut berasal dari subbagian kontrak tentang spesifikasi teknis. Spesifikasi teknis ini diambil dari Surat Edaran Dirjend Bina Marga Nomor
10/SE/Db/2014 tentang Penyampaian Standar Dokumen Pengadaan dan Spesifikasi Umum 2010 (revisi 3). Perbedaan nilai peringkat yang terjadi antara tahun 2016 dengan tahun 2017 dan 2018 terletak pada penerapan kategori AK, subkategori AK-4, kriteria 1. Pada tahun 2016 kontraktor tidak memiliki sertifikat kelaikan operasi peralatan, sedangkan pada tahun 2017 dan tahun 2018 kontraktor memiliki sertifikat kelaikan operasi peralatan. Sedangkan perbedaan item pekerjaan pada masingmasing kontrak tidak berpengaruh terhadap adanya penerapan kriteria-kriteria jalan hijau. Peningkatan penerapan kriteria-kriteria jalan hijau dapat dilakukan dengan menambahkan pasal-pasal dan persyaratan yang tertuang dalam spesifikasi teknis, syarat-syarat umum kontrak (SSUK) dan dokumen lelang sebagai sub bagian dalam dokumen kontrak.

\section{Daftar Pustaka}

[1] Ahmad, J. (2018), Desain Penelitian Analisis Isi. Tersedia di https://www.researchgate.net/publication/3 25965331.

[2] Bungin. (2001). Metodologi Penelitian Kualitatif, Jakarta : PT Raja Grafindo Persada

[3] Dinas Pekerjaan Umum Kota Payakumbuh. (2016). SPK No. 17/SPK-BM/PU-Pyk/2016, pekerjaan Rehabilitasi/ Pemeliharaan Berkala Jalan TA 2016

[4] Dinas Pekerjaan Umum dan Penataan Ruang Kota Payakumbuh. (2017). SPK No. 21/SPK-BM/PUPR-Pyk/2017, pekerjaan

\section{Informasi Artikel}

Diterima Redaksi : 18-02-2020 | Selesai Revisi : 15-04-2020 | Diterbitkan Online : 30-04-2020 
Rehabilitasi/ Pemeliharaan Berkala DAK

Penugasan

[5] Dinas Pekerjaan Umum dan Penataan

Ruang Kota Payakumbuh. (2018). SPK No.

21/SPK-BM/PUPR-Pyk/2018, pekerjaan

Rehabilitasi/ Pemeliharaan Jalan (DAK

Reguler)

[6] Ervianto, W.I. 2013. Kajian Faktor Green

Construction Infrastruktur Jalan

Berdasarkan Sistem Rating Green Road dan Invest, Konfrensi Nasional Teknik Sipil

7, Oktober 2013

[7] Hasan, M. (2011). International seminar on the green road construction and international workshop on the vetiver systems, Kementerian Pekerjaan Umum, Bandung.

[8] Frick, H \& Suskiyanto B, (2007). DasarDasar Arsitektur Ekologis, Penerbit Kanisius, Yogyakarta.

[9] Republik Indonesia. (2018). SE Menteri PUPR No. 04/SE/M2018, Pedoman Bahan Konstruksi Bangunan dan Rekayasa Sipil tentang Pemeringkatan Jalan Hijau.

[10] Republik Indonesia. (2015). Peraturan Menteri Pekerjaan Umum dan Perumahan Rakyat RI No : 05/PRT/M/2015, tentang

[11]Pedoman Umum Implementasi Konstruksi Berkelanjutan pada Penyelenggaraan Infrastruktur Bidang Pekerjaan Umum dan Permukiman Rakyat, Kemen PUPR, Jakarta.

[12]Widjanarko, A. (2009). Bangunan dan Konstruksi Hijau, Seminar Nasional Teknik Sipil V-2009, Surabaya, 11 Februari.

\section{Informasi Artikel}

Diterima Redaksi : 18-02-2020 | Selesai Revisi : 15-04-2020 | Diterbitkan Online : 30-04-2020 